\title{
Short-Term Stability of Biomarkers of Oxidative Stress and Antioxidant Status in Human Serum
}

\author{
Eugène H. J. M. Jansen, ${ }^{1}$ Piet K. Beekhof, ${ }^{1}$ Johannes W. J. M. Cremers, ${ }^{1}$ Dale Viezeliene, ${ }^{2}$ \\ Vladimira Muzakova, ${ }^{3}$ and Jiri Skalicky ${ }^{4}$ \\ ${ }^{1}$ Center for Health Protection, National Institute of Public Health and the Environment, P.O. Box 1, 3720 BA Bilthoven, The Netherlands \\ ${ }^{2}$ Department of Biochemistry, Medical Academy, Lithuanian University of Health Sciences, A. Mickeviciaus 9 , \\ 44307 Kaunas, Lithuania \\ ${ }^{3}$ Department of Biological and Biochemical Sciences, Faculty of Chemical Technology, University of Pardubice, Studentska 573, \\ 53210 Pardubice, Czech Republic \\ ${ }^{4}$ Department of Clinical Biochemistry and Diagnostics, Regional Hospital of Pardubice, Kyjevska 44, 53203 Pardubice, Czech Republic
}

Correspondence should be addressed to Eugène H. J. M. Jansen; eugene.jansen@rivm.nl

Received 16 April 2013; Accepted 26 May 2013

Academic Editors: Z. Feng and S. Paris-Palacios

Copyright (C) 2013 Eugène H. J. M. Jansen et al. This is an open access article distributed under the Creative Commons Attribution License, which permits unrestricted use, distribution, and reproduction in any medium, provided the original work is properly cited.

\begin{abstract}
The oxidation and antioxidant status of serum are often determined in serum samples which have been frozen for some time. The oxidative stress process is prone to fast alterations in the sample because of the possible instability of the reactants. Here one oxidation assay (ROM) and three antioxidant assays (FRAP, TAS, and BAP) have been tested on their performance and stability at short-time storage. The most commonly used temperatures for storage and handling of serum samples $\left(+4\right.$ and $\left.+20^{\circ} \mathrm{C}\right)$ were selected. In three short-term studies in which the storage time varied between 3 and $48 \mathrm{hrs}$ the performance of these assays were tested on human serum samples. The general conclusion is that most assays performed well and gave stable results during 2 days of storage of the samples at both temperatures. Only the FRAP and TAS assays showed a small deviation at some storage conditions. In conclusion, handling of serum samples at +4 and $+20^{\circ} \mathrm{C}$ during short-time periods did not affect the quality and performance of the oxidation and antioxidant assays during day-to-day analyses.
\end{abstract}

\section{Introduction}

In epidemiological and clinical research the stability of biomarkers in serum or plasma samples during sample preparation and after storage is of great importance. This procedure is part of the whole process of blood withdrawal, blood processing to serum or plasma, and storage of the end products [1]. The storage conditions after sample preparation must also be adequate to maintain the same outcome of the assays.

The oxidation and antioxidant status of serum can be determined by several commercially available assays. In epidemiological and also other large-scale studies the storage of serum samples during a working day in between the measurements and the day-to-day assay variation and performance are very important to obtain reliable results.
The antioxidant status can be determined by adding the contribution of several components of the antioxidant system. A faster and cheaper way for the determination of the total antioxidant capacity is to perform only one assay in which all components contribute to an integrating value [24]. The biomarkers of oxidative stress and antioxidant status are important to assess a physiologically altered state [5], to detect adverse nutritional habits [6] or an increased disease state $[7,8]$.

In the present study the stability and performance of a number of different commercially available assays have been tested on human serum samples which have been stored at different temperatures for a short-term period up to 2 days. These assays include an oxidative stress assay for hydroperoxides which measures the reactive oxygen metabolites (ROM), the ferric ability of plasma (FRAP), the 
total antioxidant status (TAS), and the biological antioxidant potential (BAP). These oxidation-related assays are suitable to measure on autoanalyzers in large-scale studies. All these assays have shown their value in several studies.

\section{Materials and Methods}

2.1. Human Volunteers. For the 1-to-9-day stability study of the ROM and FRAP assays, four volunteers donated blood and within two hours after blood withdrawal serum samples were prepared, divided in aliquots, and stored immediately at $-80^{\circ} \mathrm{C}$. On days $1,2,3$, and 9 aliquots were taken and kept at room temperature for 4 hours. Then the assay measurements were performed in duplicate. The study was conducted with written approval of the participants.

For the three hours stability study of the ROM and FRAP assays, six volunteers donated blood and within two hours after blood withdrawal serum samples were prepared. The measurements of ROM and FRAP were performed in quadruplicate, at $t=0$ and at $t=90$ and $180 \mathrm{~min}$. The study was conducted with written approval of the participants.

For the 2-day stability study of the ROM, BAP, and TAS assays, serum samples of 34 human volunteers were used. At the day of blood withdrawal the serum samples were prepared within two hours and stored at $-80^{\circ} \mathrm{C}$. After shipment to Bilthoven on dry ice, the samples were divided in aliquots and stored at $+4^{\circ} \mathrm{C}$ and $+20^{\circ} \mathrm{C}$ for 24 and $48 \mathrm{hrs}$. The initial concentrations for the parameters at $t=0$ were determined in duplicate at the day of storage. The study was conducted with approval of the Ethics Committee of the Regional Hospital Pardubice under the supervision of MUDr. Josef Hájek C.S., with written permission of the volunteers.

2.2. Measurements of Parameters. The parameters ROM, TAS, and BAP have been determined in serum with an autoanalyzer (LX20 Pro, Beckman-Coulter, Woerden, the Netherlands). TAS [9] was obtained from Rel Assay Diagnostics, Gaziantep, Turkey, and ROM and BAP from Diacron, Grosseto, Italy. The FRAP assay was performed as described by Benzie and Strain [10].

At all time points the statistical difference (95\% confidence interval) of the values from the initial value at $t=0$ was determined with a $t$-test for two samples assuming equal variances.

In the figures the means \pm standard deviations are shown, whereas at $t=0$ the standard deviation of the method is indicated.

\section{Results}

\subsection{Short-Term Stability of the Oxidation Assay}

3.1.1. The ROM Assay. In a first study the short term stability and performance of the ROM assay were investigated in serum samples which have been kept at room temperature up to $3 \mathrm{hrs}$. In this study six human samples were used and measurements were done at $t=0$ (10 min after defrosting) and after 90 and $180 \mathrm{~min}$. The measurements were performed

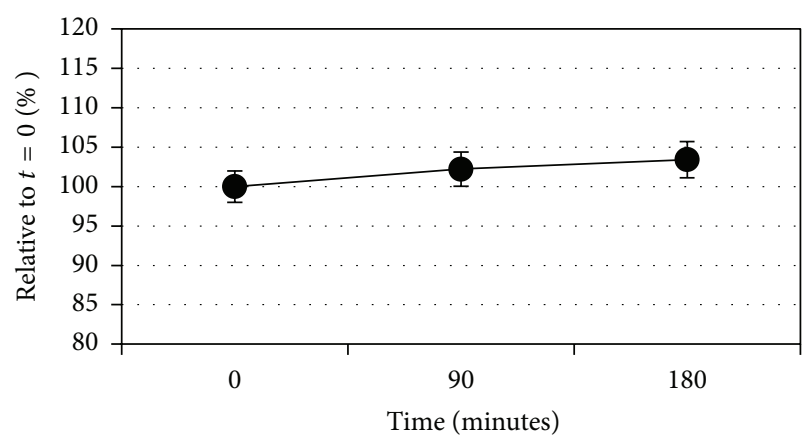

FIGURE 1: Short-time stability of the ROM assay (mean $\pm s d$ ) in human serum samples $(N=6)$ upon storage at room temperature.

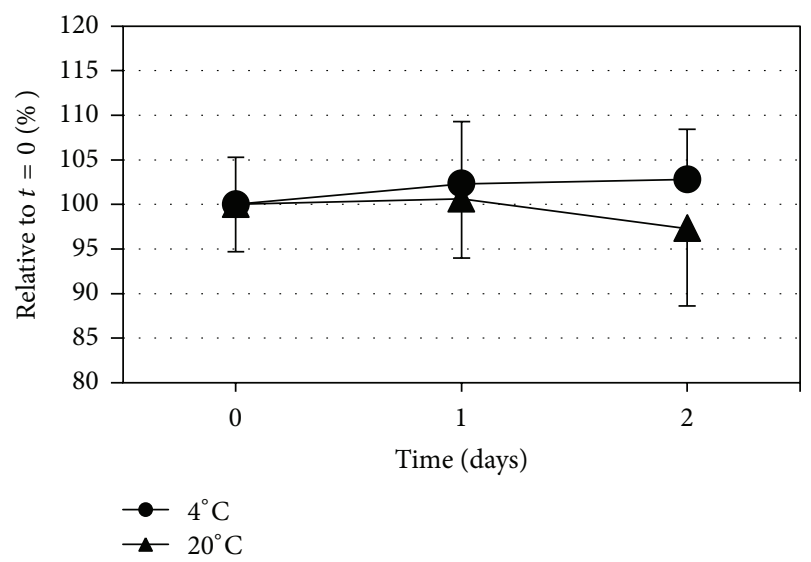

FIGURE 2: Short-time stability of the ROM assay (mean $\pm \mathrm{sd}$ ) in human serum samples $(N=32)$ upon storage at two different temperatures.

in quadruplicate. In Figure 1 the means \pm standard deviations of the ROM assay of the six samples are shown. A slight increase in time was observed, but the increase was not statistically significant.

To test the stability and performance of the ROM assay during longer periods, the sera of 32 volunteers were defrosted and kept at two different temperatures ( +4 and $+20^{\circ} \mathrm{C}$ ) for two days. The ROM assays were performed at $t=0$ and after 24 and 48 hrs. The results (means \pm standard deviations) are shown in Figure 2. A slight time-dependent increase to $102.8 \%$ at $+4^{\circ} \mathrm{C}$ and a decrease to $97.3 \%$ at $+20^{\circ} \mathrm{C}$ were observed. Both changes in time were not statistically significant. Also the difference at day 2 between the two temperatures was not statistically significant.

In large epidemiological studies, it is essential to maintain the quality and precision of the assay constant. For the ROM assay we tested whether the assay applied to human samples gives reliable results for a number of consecutive days. In this study four human serum samples were defrosted and kept at room temperature for $4 \mathrm{hrs}$. After $4 \mathrm{hrs}$ the ROM assay was performed in quadruplicate. Then the samples were aliquoted and frozen again at $-80^{\circ} \mathrm{C}$. The measurements as performed at day 0 were repeated on days 1, 2, 3, and 9. In Figure 3 the means \pm standard deviations of the ROM assay are shown. No 


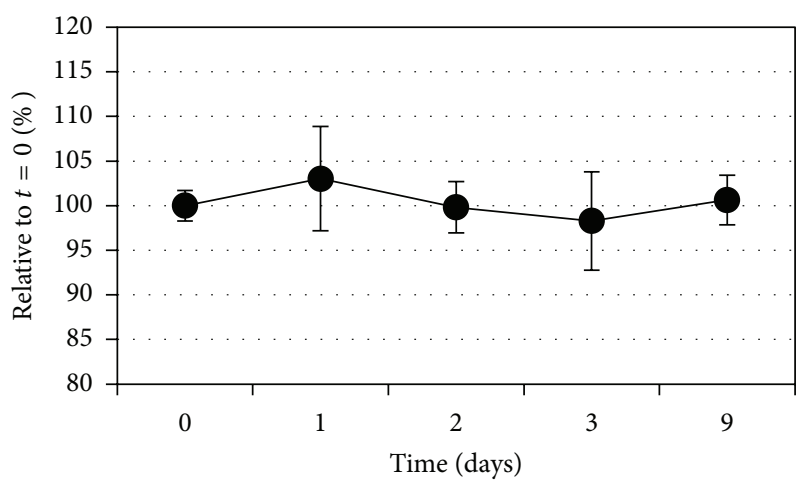

FIgure 3: Performance of the ROM assay (mean $\pm s d$ ) in human serum samples $(N=4)$ on different days. On each day, the serum samples were kept for four hours at room temperature.

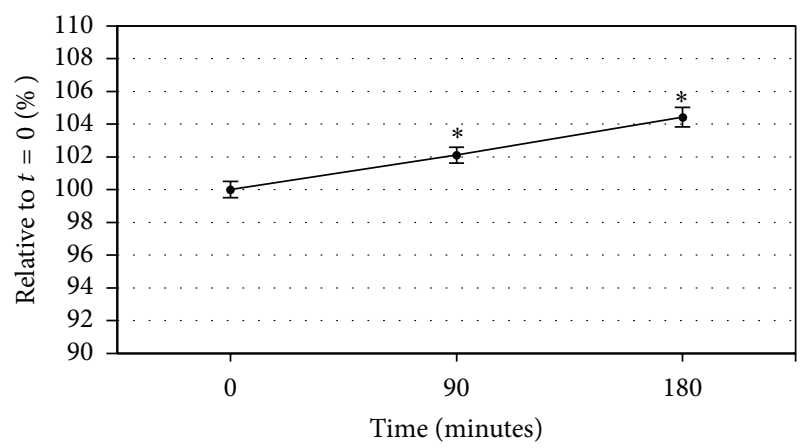

FIGURE 4: Short-time stability of the FRAP assay (mean \pm sd) in human serum samples $(N=6)$ upon storage at room temperature. Statistically significant differences relative to the value at $t=0$ have been indicated with an asterix.

statistically significant changes were observed relative to the measurement at day 0 .

\subsection{Short-Term Stability of the Antioxidant Assays}

3.2.1. The FRAP Assay. The short term stability and performance of the FRAP assay were investigated in serum samples which have been kept at room temperature up to 3 hrs. In this study six human samples were used and measurements were done at $t=0$ (10 min after defrosting) and after 90 and $180 \mathrm{~min}$. The measurements were done in 4-fold. The result is shown in Figure 4. A statistically significant increase in the mean level of the FRAP assay to 102.1 and $104.4 \%$ with $P$ values $<0.0005$ was observed in time, which was also due to the low standard deviation of the assay in this study.

For the FRAP assay we tested also whether the assay gives reliable results for a number of consecutive days. In this study four human serum samples were defrosted and kept at room temperature for $4 \mathrm{hrs}$. After $4 \mathrm{hrs}$ the FRAP assay was performed in quadruplicate. This was repeated on days 1, 2, 3, and 9. The result is shown in Figure 5. At all days, no statistically significant changes were observed relative to the measurement at day 0 .

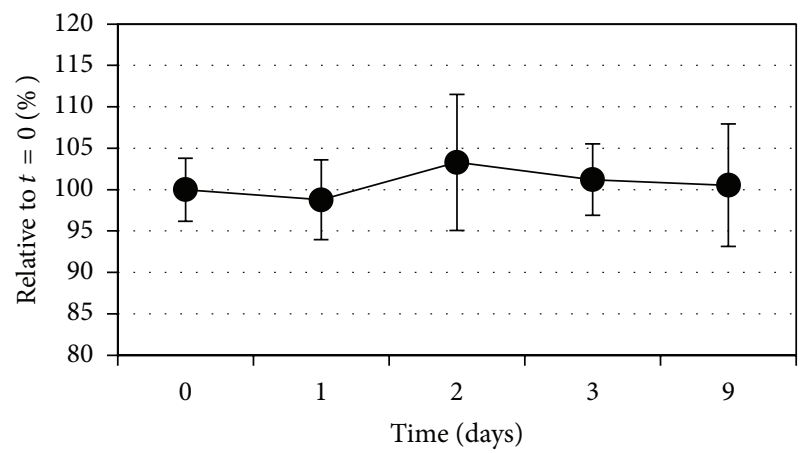

FIgURE 5: Performance of the FRAP assay (mean $\pm s d$ ) in human serum samples $(N=4)$ on different days. On each day, the serum samples were kept for four hours at room temperature.

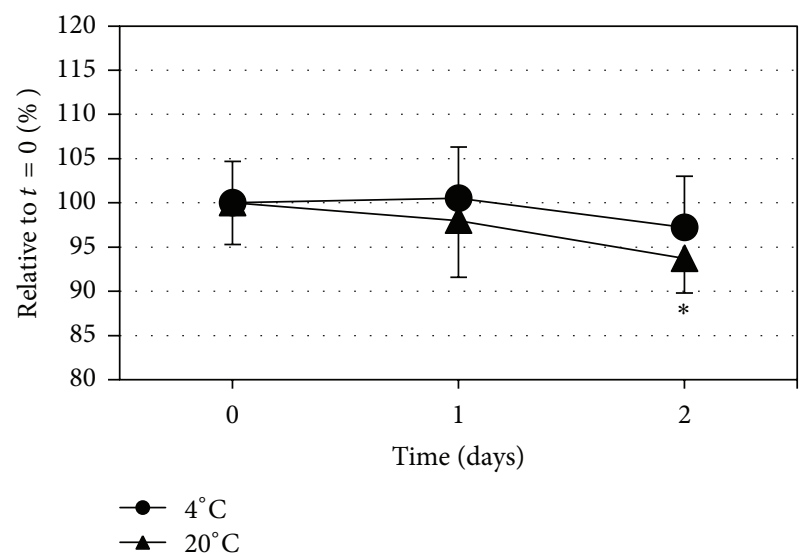

FIgURE 6: Short-time stability of the TAS assay (mean $\pm \mathrm{sd}$ ) in human serum samples $(N=32)$ upon storage at two different temperatures. Statistically significant differences relative to the value at $t=0$ have been indicated with an asterix.

3.2.2. The TAS Assay. To test the stability and performance of the TAS assay during longer periods, the sera of 32 volunteers were defrosted and kept at two different temperatures for two days. The TAS assay was performed at $t=0$ and after 24 and $48 \mathrm{hrs}$. A decrease was observed at both temperatures as is shown in Figure 6, to $97.2 \%$ (at $+4^{\circ} \mathrm{C}$ ) and to $93.7 \%$ (at $+20^{\circ} \mathrm{C}$ ). The means of the TAS assay at day 2 for samples stored at $+20^{\circ} \mathrm{C}$ were statistically significantly different from the mean at day 0 with $P$ values of $<0.005$. Also the difference of the means of both temperatures at day 2 is both statistically and significantly different $(P<0.019)$. The correlation between both sets of samples at day 2 , however, was still very good (0.92). This means that the rank order was not affected by the storage conditions.

3.2.3. The BAP Assay. The stability and performance of the $\mathrm{BAP}$ assay was tested also during longer periods at $t=0$ and after 24 and $48 \mathrm{hrs}$. As shown in Figure 7 a small increase was observed to $104.8 \%$ (at $+4^{\circ} \mathrm{C}$ ) and to $103.7 \%$ (at $+20^{\circ} \mathrm{C}$ ). But all changes were not statistically significantly different from each other. Also no statistically significant differences were 


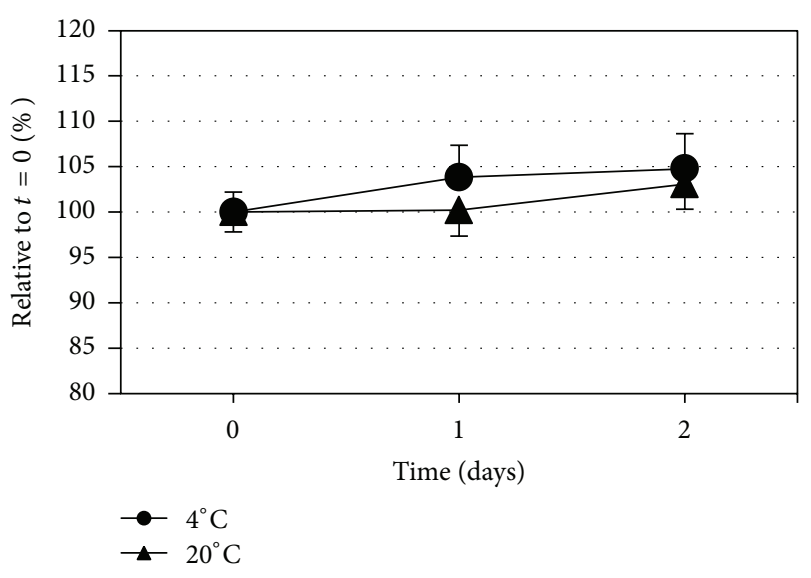

FIgURE 7: Short-time stability of the BAP assay (mean \pm sd) in human serum samples $(N=32)$ upon storage at two different temperatures.

observed for the means at the two temperatures at the same day.

\section{Discussion}

The oxidation and total antioxidant status of serum can be determined by several commercially available assays. Here the stability of the oxidation assay ROM and of 3 antioxidant assays, FRAP, TAS, and BAP, was tested in human serum samples after short-term storage at two temperatures (4 and $20^{\circ} \mathrm{C}$ ). The general conclusion is that all assays gave good and similar results using human serum samples stored at all conditions tested.

The ROM assay showed no statistically significant increase or decrease during all the studies. Even up to 2 days no decrease could be observed when stored at $+20^{\circ} \mathrm{C}$.

The FRAP assay showed in one study a statistically significant increase in the mean value during storage for $3 \mathrm{hrs}$ at room temperature. But this was not observed during a 4-day study in which the samples were kept at room temperature for $4 \mathrm{hrs}$. The statistically significant increase is probably due to the low standard deviations in first study.

The TAS assay showed a small, but statistically significant, decrease during 2 days of storage at room temperature. The rank order, between the two sets of samples, however, was not affected, which means that statistical analyses can still be performed on these data.

The BAP assay showed a small, but not statistically significant, increase of the mean value during 2 days of storage at room temperature.

The short-term stability of the various assays tested in this study is rather good when applied to human serum samples. This is an important observation for laboratories who are involved in large-scale biomarker measurements. The handling of many samples requires a certain processing time with an unavoidable storage time at +4 or $+20^{\circ} \mathrm{C}$. It is somewhat surprising to see that especially the ROM assay, representing a biomarker for oxidative stress, is most stable during these short-term storage experiments. Full automation makes this assay very suitable for large-scale epidemiological studies [8].

Although all three antioxidant assays did perform well to determine the total antioxidant status in serum [11], the BAP assay was most stable in our hands and can be automated in addition. The antioxidant assays FRAP and TAS are somewhat more sensitive for storage at room temperature under certain conditions.

In conclusion, all assays performed well and gave stable results during 2 days of storage at +4 or $+20^{\circ} \mathrm{C}$. Therefore handling of serum samples at +4 or $+20^{\circ} \mathrm{C}$ during a period of about 4 hours is allowed to maintain the quality and performance of the assays. But if possible storage at +4 instead of $+20^{\circ} \mathrm{C}$ is advisable to maintain a proper assay outcome during the day-to-day analyses of large-scale biomarker studies.

In the literature, not many reports on the storage stability of total antioxidant assays can be found. There are only a few reports about the stability of the individual antioxidants present in serum or plasma $[12,13]$, but not at short-term storage. Therefore the present study gives valuable information on the short-term stability of a number of oxidation-related assays.

\section{Conflict of Interest}

The authors stated that there is no conflict of interests regarding the publication of this paper. Research support played no role in the study design, in the collection, analysis and interpretation of data, in the writing of the paper, or in the decision to submit the paper for publication.

\section{References}

[1] G. Lippi, J. J. Chance, S. Church et al., "Preanalytical quality improvement: from dream to reality," Clinical Chemistry and Laboratory Medicine, vol. 49, no. 7, pp. 1113-1126, 2011.

[2] D. Koracevic, G. Koracevic, V. Djordjevic, S. Andrejevic, and V. Cosic, "Method for the measurement of antioxidant activity in human fluids," Journal of Clinical Pathology, vol. 54, no. 5, pp. 356-361, 2001.

[3] I. S. Young, "Measurement of total antioxidant capacity," Journal of Clinical Pathology, vol. 54, no. 5, p. 339, 2001.

[4] G. Cao and R. L. Prior, "Comparison of different analytical methods for assessing total antioxidant capacity of human serum," Clinical Chemistry, vol. 44, no. 6, pp. 1309-1315, 1998.

[5] A. Ghiselli, M. Serafini, F. Natella, and C. Scaccini, "Total antioxidant capacity as a tool to assess redox status: critical view and experimental data," Free Radical Biology and Medicine, vol. 29, no. 11, pp. 1106-1114, 2000.

[6] C. Kusano and B. Ferrari, "Total antioxidant capacity: a biomarker in biomedical and nutritional studies," Journal of Cell and Molecular Biology, vol. 7, no. 1, pp. 1-15, 2008.

[7] S. Sarbana, A. Kocyigitb, M. Yazaram, and U. E. Isikana, "Plasma total antioxidantcapacity, lipid peroxidation, and erythrocyte antioxidant enzyme activities in patients with rheumatoid arthritis and osteoarthritis," Clinical Biochemistry, vol. 38, no. 11, pp. 981-986, 2005.

[8] A. M. Leufkens, F. J. B. van Duijnhoven, S. H. S. Woudt et al., "Biomarkers of oxidative stress and risk of developing 
colorectal cancer: a cohort-nested case-control study in the European prospective investigation into cancer and nutrition," The American Journal of Epidemiology, vol. 175, no. 7, pp. 653663, 2012.

[9] O. Erel, "A novel automated direct measurement method for total antioxidant capacity using a new generation, more stable ABTS radical cation," Clinical Biochemistry, vol. 37, no. 4, pp. 277-285, 2004.

[10] I. F. F. Benzie and J. J. Strain, "The ferric reducing ability of plasma (FRAP) as a measure of "antioxidant power": the FRAP assay," Analytical Biochemistry, vol. 239, no. 1, pp. 70-76, 1996.

[11] E. H. J. M. Jansen and T. Ruskovska, "Comparative analysis of serum (Anti)oxidative status parameters in healthy persons," International Journal of Molecular Sciences, vol. 14, no. 3, pp. 6106-6115, 2013.

[12] S. S. Tworoger and S. E. Hankinson, "Collection, processing, and storage of biological samples in epidemiologic studies: sex hormones, carotenoids, inflammatory markers, and proteomics as examples," Cancer Epidemiology Biomarkers and Prevention, vol. 15, no. 9, pp. 1578-1581, 2006.

[13] E. H. Jansen, P. K. Beekhof, J. W. Cremers, D. Viezeliene, V. Muzakova, and J. Skalicky, "Long term stability of parameters of antioxidant status in human serum," Free Radical Research, vol. 47, no. 6-7, pp. 535-540, 2013. 


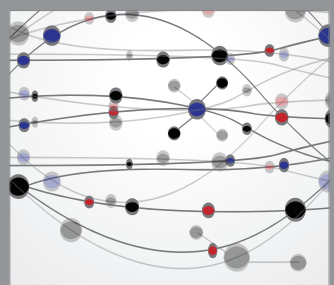

The Scientific World Journal
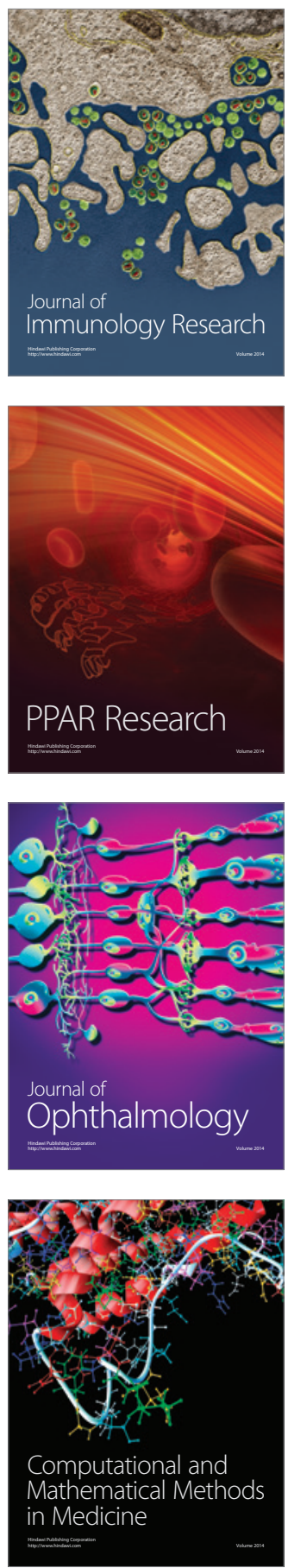

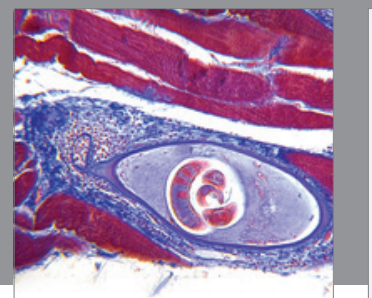

Gastroenterology

Research and Practice
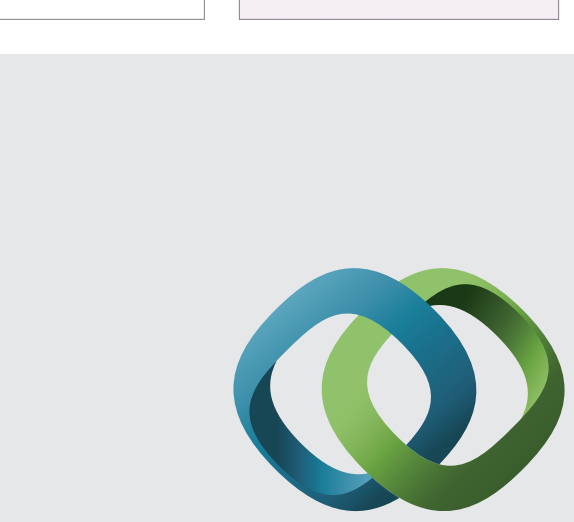

\section{Hindawi}

Submit your manuscripts at

http://www.hindawi.com
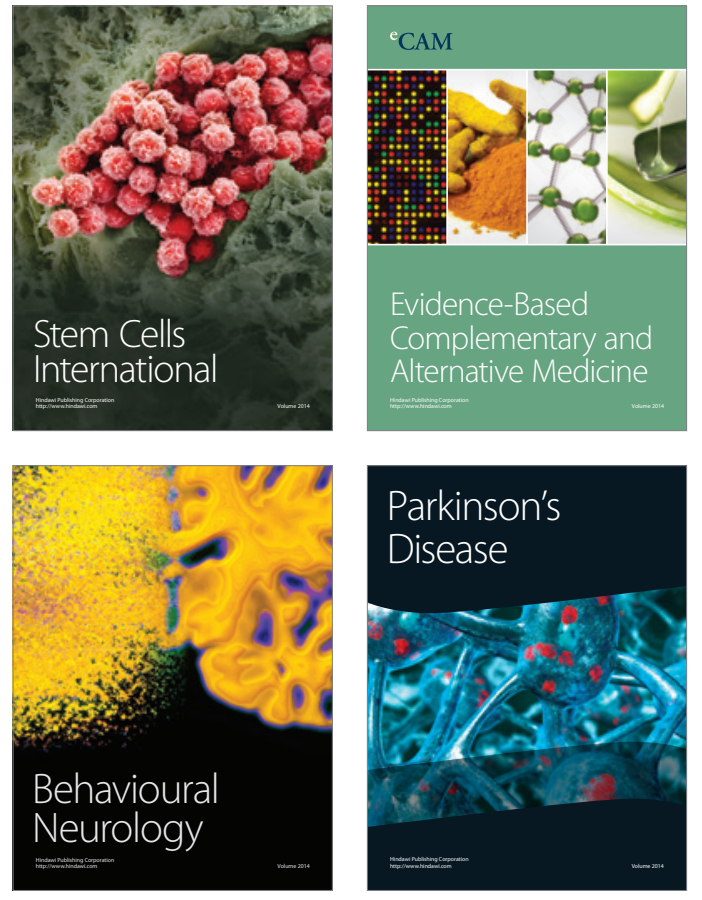
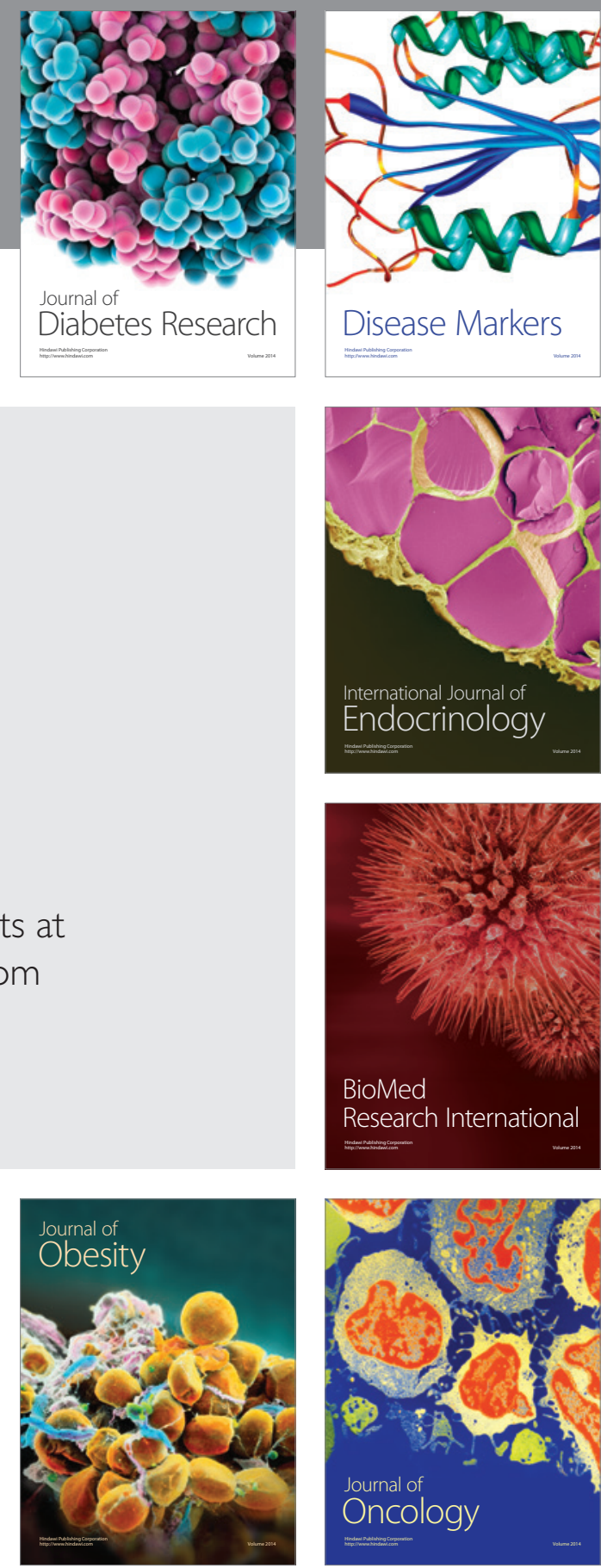

Disease Markers
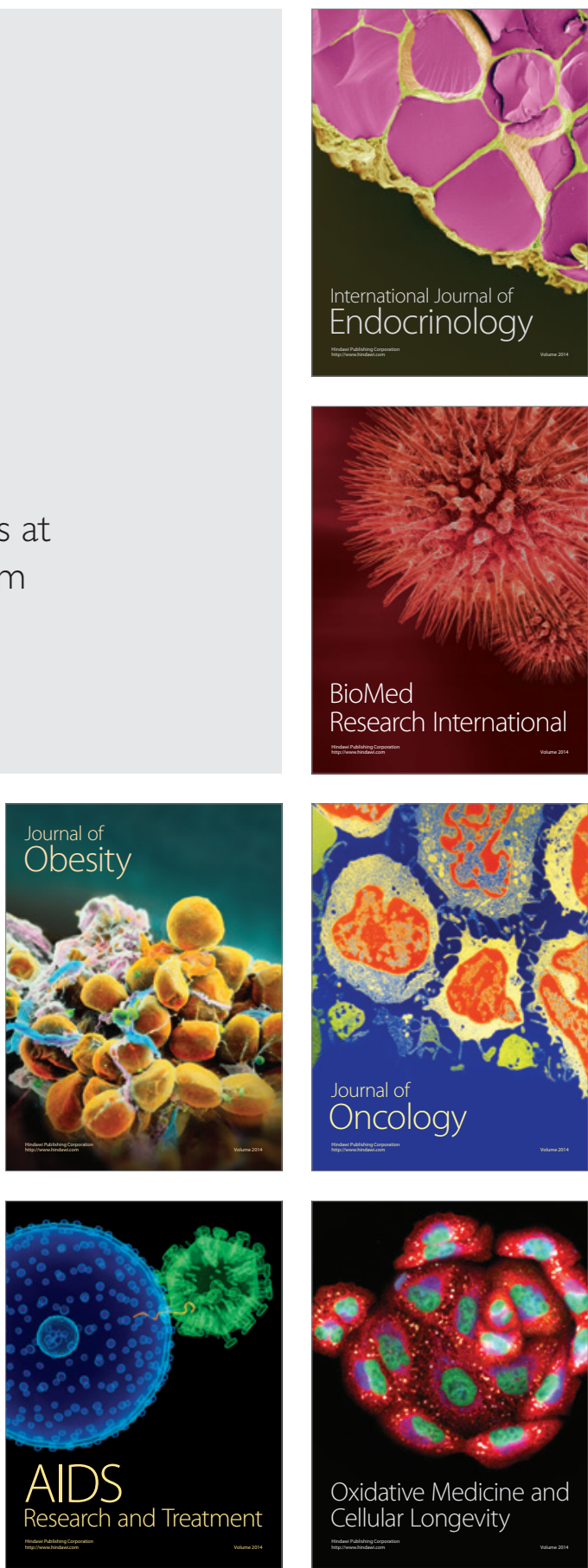